\title{
Preliminary observations of cadmium and copper effects on juveniles of the polychaete Capitella sp. Y (Annelida: Polychaeta) from Estero del Yugo, Mazatlán, México
}

\author{
Observaciones preliminares de los efectos de cadmio y cobre sobre juveniles del poliqueto \\ Capitella sp. Y (Annelida: Polychaeta) del Estero del Yugo, Mazatlán, México
}

\author{
NURIA MÉNDEZ* \& CARLOS GREEN-RUIZ
}

\begin{abstract}
Unidad Académica Mazatlán, Instituto de Ciencias del Mar y Limnología, Universidad Nacional Autónoma de México, Apartado Postal 811, Mazatlán, Sinaloa 82000, México;

*e-mail for correspondence: nuri@ola.icmyl.unam.mx
\end{abstract}

\begin{abstract}
The effects of cadmium $(\mathrm{Cd})$ and copper $(\mathrm{Cu})$ on cultured juveniles of Capitella sp. Y were investigated. Seven-day old juveniles were exposed to 13 (control), 60, 160, 240 and $340 \mu \mathrm{g} \mathrm{Cd} \mathrm{L}^{-1}$ and 17 (control), 50, 120 and $150 \mu \mathrm{g} \mathrm{Cu} \mathrm{L}^{-1}$ for 30 days. Mortality significantly increased with increasing $\mathrm{Cu}$ concentrations, but in $\mathrm{Cd}$ exposures, it was only evident at $340 \mu \mathrm{g} \mathrm{L}^{-1}$. Body size and faecal pellet production were reduced earlier in juveniles exposed to $\mathrm{Cu}$ than those exposed to $\mathrm{Cd}$, especially in the higher $\mathrm{Cu}$ concentrations. These facts indicate that juveniles are more sensitive to $\mathrm{Cu}$ in terms of mortality, feeding and growth. Haemoglobin production was inhibited due to the scarcity of food in the experimental sediment rather than to metal exposure. Tube building was not affected by the presence of metals or by the scarcity of food. This study suggests that $\mathrm{Cu}$ concentrations from 50 to $150 \mu \mathrm{g} \mathrm{L}^{-1}$ and $340 \mu \mathrm{g} \mathrm{L}^{-1}$ of $\mathrm{Cd}$ could affect the population dynamics of this species in natural ecosystems.
\end{abstract}

Key words: bioassays, marine worms, mortality, juveniles, heavy metals.

\section{RESUMEN}

Se investigaron los efectos de cadmio $(\mathrm{Cd})$ y cobre $(\mathrm{Cu})$ sobre juveniles cultivados de Capitella sp. Y. Organismos juveniles de siete días de edad fueron expuestos a 13 (control), 60, 160, 240 y $340 \mu \mathrm{g} \mathrm{Cd} \mathrm{L}^{-1}$ y a 17 (control), 50, 120 y $150 \mu \mathrm{g} \mathrm{Cu} \mathrm{L}{ }^{-1}$ durante 30 días. La mortalidad se incrementó significativamente al aumentar las concentraciones de $\mathrm{Cu}$ y, en las exposiciones a $\mathrm{Cd}$, solamente fue evidente a $340 \mu \mathrm{g} \mathrm{L}^{-1}$. El tamaño corporal y la producción de heces fecales disminuyeron antes en los especímenes expuestos a $\mathrm{Cu}$ que en los expuestos a $\mathrm{Cd}$, especialmente en las concentraciones más altas de $\mathrm{Cu}$. Estos resultados indican que los juveniles son más sensibles al $\mathrm{Cu}$ en términos de mortalidad, alimentación y crecimiento. La producción de hemoglobina fue inhibida debido a la escasez de alimento en el sedimento experimental, más que a exposición a los metales. La formación de tubos no fue afectada por la presencia de metales ni por la escasez de alimento. Este estudio sugiere que concentraciones entre 50 y $150 \mu \mathrm{g} \mathrm{L}^{-1}$ de $\mathrm{Cu}$ y de $340 \mu \mathrm{g} \mathrm{L}^{-1}$ de Cd, podrían afectar la dinámica poblacional de esta especie en ecosistemas naturales.

Palabras clave: bioensayos, gusanos marinos, mortalidad, juveniles, metales pesados.

\section{INTRODUCTION}

The endobenthic deposit feeder Capitella capitata (Fabricius, 1780) has been considered as an indicator of organic pollution in marine sediments (e.g., Pearson \& Rosenberg 1978, Méndez et al. 1997). It consists of a speciescomplex of morphologically similar specimens that do not crossbreed. They are distinguishable by enzyme and general protein patterns studied through electrophoresis (Grassle \& Grassle 1974, Grassle \& Grassle 1976, Wu et al. 1991), by developmental and reproductive features (Pearson \& Pearson 1991, Wu et al. 1991, Linke-Gamenick et al. 2000a, Méndez et al. 2000), and by ecophysiological characters, such as tolerance to abiotic factors and respiration rates (Gamenick \& Giere 1994, Gamenick et al. 
1998a, Gamenick et al. 1998b, Linke-Gamenick et al. 2000b). Capitella capitata has been widely utilised as test species in toxicological bioassays (Reish \& LeMay 1991).

Results from a preliminary study (Méndez, unpublished data) concerning the reproductive mode, the larval development and growth of cultured Capitella (hereafter termed Capitella sp. Y) from the Estero del Yugo indicated that this species has a lecithotrophic development and a lifespan of more than one year. Twenty nine to 123 ciliated metatrochophore larvae $(0.399 \pm 0.098 \mathrm{~mm}, \mathrm{n}=43)$ hatch on day one from a single brood and swim in the water column for a variable period from day one to day five before settling into the sediment. Metamorphosis to the juvenile stage can be produced from the first day (after hatching as metatrochophores) until day 21 , when feeding activity and tube building begins. The juvenile stage is characterised by the vermiform shape with complete segmentation, a clear distinction between thorax and abdomen, the presence of two small eyes, and the presence of capillary chaetae in the three first segments and hooded hooks in the subsequent segments. Transparent juveniles $(2.253 \pm 1.616 \mathrm{~mm}, \mathrm{n}=726)$ were observed from day one to day 12 after which they became pink to red due to haemoglobin production as individuals began to reach the adult stage.

Heavy metals enter the marine environment via rainfall, river run-off, domestic and industrial discharges and fall-out from air pollution and can adhere to particulates present in the water column (Duedall et al. 1983). Eventually, many of these particulates with their associated toxicants sink to the benthos (Reish \& LeMay 1991). Observations made by Reish (1988) indicate that the relative toxicity of metals to polychaetes in decreasing order is copper $(\mathrm{Cu})$, mercury $(\mathrm{Hg})$, zinc $(\mathrm{Zn})$, arsenic (As), chrome $(\mathrm{Cr})$, and cadmium (Cd). Cadmium and $\mathrm{Cu}$ were chosen in this study according to this tabulation. Cadmium is a nonessential metal with a low relative toxicity to polychaetes whose seawater levels are normally found in the field from $0.005 \mu \mathrm{g} \mathrm{L}^{-1}$ (Nürnberg 1977) to $130 \mu \mathrm{g} \mathrm{L}^{-1}$ (Förstner \& Wittmann 1981). Even though copper is an essential metal, it is one of the most toxic elements to polychaetes. Its concentrations in seawater range from $0.13 \mu \mathrm{g} \mathrm{L}^{-1}$ (Nürnberg 1977) to 36.2 $\mu \mathrm{g} \mathrm{L}^{-1}$ (Roth \& Hornung 1977). Nevertheless, values as high as $88 \mu \mathrm{g} \mathrm{Cu} \mathrm{L}^{-1}$ have been found in a copper mine tailing discharge from Chile (CIMM 1996).

Few studies have been performed to test the effects of $\mathrm{Cd}$ and $\mathrm{Cu}$ within the Capitella species-complex (Reish et al. 1976, Reish 1988, Reish \& LeMay 1991), but none of them is referred to juveniles. The aims of this study were to provide preliminary observations on the effects of these metals on mortality, tube building, pellet production, body size and haemoglobin production of Capitella sp. Y juveniles.

MATERIAL AND METHODS

\section{Worms}

Specimens of Capitella sp. Y were collected during January 2002 from Estero del Yugo, a lagoon with a temporary connection to the sea that is located in the north of the city of Mazatlán, on the Pacific coast of México $\left(23^{\circ} 17^{\prime} 54^{\prime \prime} \mathrm{N}, 106^{\circ} 29^{\prime} 01^{\prime \prime} \mathrm{W}\right)$. The worms were collected using a shovel at $0.5 \mathrm{~m}$ depth. The sediment (organic matter content $=6.5 \pm 2.5 \%$, $\mathrm{n}=4$ ) was sieved through a $0.5 \mathrm{~mm}$ mesh, which retained the worms that were collected with forceps. Worms were cultured in the laboratory for 10 months prior to the experiment in $20 \times 30 \mathrm{~cm}$ aquarium tanks (about 200 worms per tank) containing each, a 2 to $4 \mathrm{~cm}$ layer of sediment from the beach in front of Hotel Playa, Mazatlán, which had previously been sieved to a grain size less than $250 \mu \mathrm{m}$ in diameter and frozen. Previous experiences in the laboratory (Méndez, unpublished data) have demonstrated that this sediment is appropriate to culture this species. The tanks contained $1.5 \mathrm{~L}$ of aereated and UVfiltered seawater $(34 \% 0)$ and were maintained at $23 \pm 1{ }^{\circ} \mathrm{C}$ in the dark. Animals were fed weekly with $0.5 \mathrm{~g}$ per culture of artificial food, which consisted of a mixture of equal parts of commercial fish food (Sera vipan), and dried spinach (Forbes et al. 1996).

\section{Experimental design}

Twenty Capitella sp. Y brooding females with developing embryos inside tubes were isolated 
from the stock culture and placed in dishes containing $1 \mathrm{~g}$ dry weight of $<250 \mu \mathrm{m}$ sediment, $0.01 \mathrm{~g}$ dry weight of artificial food (weekly addition) and $7 \mathrm{~mL}$ of seawater at $23 \pm 1{ }^{\circ} \mathrm{C}$ in the dark. Daily observations were carried out using an Olympus SZH10 Stereoscopic microscope. After hatching and settling, 7-day old juveniles necessary for the experiment with $\mathrm{Cd}$ and $\mathrm{Cu}$ were removed. These specimens presented the characteristic juvenile features and measured at least 2.25 $\mathrm{mm}$ length. The rest of the individuals were maintained in the same culture conditions in order to compare the exposed juveniles with unstressed specimens. These individuals were considered as "controls with food" and daily observations were carried out during the experiment.

Five seven-day old juveniles from three brooding tubes were randomly transferred with forceps to $3.5 \mathrm{~cm}$ diameter plastic cell-wells containing $0.03 \mathrm{~g}$ wet weight of artificial foodenriched sediment, which was prepared by the addition of $0.1 \mathrm{~g}$ (dry weight) of artificial food to $10 \mathrm{~g}$ (dry weight) of sediment to allow feeding of the organisms at least during the first part of the experiment. No extra food was added to avoid possible variations of metal concentrations in the experimental solutions. Five $\mathrm{mL}$ of metal solution with different $\mathrm{Cd}$ and $\mathrm{Cu}$ concentrations were added to the dishes, except for control dishes, where $5 \mathrm{~mL}$ of seawater $(34 \%$ ) were added. According to the availability of same-aged specimens (sevenday old), two replicates were analysed for each treatment, making a total of 10 juveniles per concentration. The same controls were utilised for the two metals. The experimental conditions were maintained at $23 \pm 1{ }^{\circ} \mathrm{C}$ in the dark during the whole experiment. Daily observations of the organisms under the stereoscopic microscope were performed until death of all the specimens (30 days). Every seven days, the $\mathrm{Cd}$ and $\mathrm{Cu}$ solutions were removed under the microscope using a pipette and were replaced by $5 \mathrm{~mL}$ of new test solutions. This replacement period was chosen to avoid stressing the specimens. Mortality was quantified when individuals did not show any movement when disturbed.

Due to the small body size of the organisms, as well as their movement and burrowing activity, qualitative observations under the microscope instead of quantitative measurements were carried out in order to avoid stressing the specimens. Pellet production (observed by transparency inside the gut) and shrinkage (body size reduction), were recorded in order to have an approach of the effect of these metals on juvenile feeding activity and growth, respectively. The change of colour of the specimens was considered as an indicator of haemoglobin production. Tube building activity was recorded by direct observations of juveniles inside tubes and by the presence of empty tubes in the sediment.

\section{Metal solutions}

Cadmium and $\mathrm{Cu}$ commercial standard solutions $\left(1 \mu \mathrm{g} \mathrm{L}^{-1}\right)$ from Sigma de México, S.A. were diluted in UV-filtered seawater (34 $\% o$ ) to prepare the experimental metal solutions at the beginning of the experiment. Samples of each solution were taken at the beginning of the experiment and every seven days, after each solution replacement. The actual total dissolved $\mathrm{Cd}$ and $\mathrm{Cu}$ concentrations were measured after acidification with nitric acid with a Graphite Furnace Atomic Absorption Spectrometer (Model SpectrAA 220 from Varian), using a wavelength of $228.8 \mathrm{~nm}$ for $\mathrm{Cd}$ and $327.4 \mathrm{~nm}$ for $\mathrm{Cu}$. All glassware and plastic devices were thoroughly acid-washed (Moody \& Lindstrom 1977).

The control metal concentrations correspond to the natural UV-filtered seawater used in the experiments. Since no significant differences resulted among samples measured at the beginning and at the end of the seven-day periods, the values measured at the beginning were considered for each treatment over the experiment. Thus, the actual $\mathrm{Cd}$ concentrations of the solutions were 13 (control), 60, 160, 240 and $340 \mu \mathrm{g} \mathrm{L}^{-1}$, while those for $\mathrm{Cu}$ were 17 (control), 50, 120 and $150 \mu \mathrm{g} \mathrm{L}^{-1}$. These ranges of $\mathrm{Cd}$ and $\mathrm{Cu}$ concentrations used in test solutions consider those found in nature and were chosen based on the experiences reported by Reish et al. (1976) and Reish \& LeMay (1991) with a Capitella capitata population.

\section{Statistics}

The effect of metal concentrations on juvenile mortality was tested by the Friedman ANOVA 
non-parametric test for difference of means (pairs test) over the experimental time (Zar 1996), since no normality in data was found. The mean daily mortality percentages for each treatment were compared with the Statistica, version 5.5, 2000 program. The $\mathrm{LC}_{50}$ and $\mathrm{LT}_{50}$ were determined, when possible, for the different experimental days and concentrations, respectively, by the probit method (Finney 1971), which consists of a straight-line graphical interpolation (Toxic MS Dos program, version 1.0, 1990).

\section{RESULTS}

Juvenile mortality did not show a clear trend associated to $\mathrm{Cd}$ concentrations, since the Friedman ANOVA non-parametric test results indicated that mean mortalities at 60 and 340 $\mu \mathrm{g} \mathrm{L}^{-1}$ were significantly different to those of the control, while intermediate concentrations were not significantly different to the control (Table 1). However, an earlier mortality was observed in specimens exposed to $340 \mu \mathrm{g} \mathrm{L}^{-1}$ (Table 2). On the contrary, juvenile mortality was high and increased with increasing $\mathrm{Cu}$ concentrations over the experiment (Table 3), which was confirmed by the Friedman ANOVA test, where means of samples were significantly different among treatments (including controls), except between 120 and $150 \mu \mathrm{g} \mathrm{L}^{-1}$ (Table 1). Results of $\mathrm{LC}_{50}$ and $\mathrm{LT}_{50}$ are reported only for the cases when data significantly fitted the probit lines. $\mathrm{LC}_{50}$ values for $\mathrm{Cu}$, with their respective lower and upper limits, were: $81 \mu \mathrm{g} \mathrm{L}^{-1}$ (59-102) for day $7 ; 73 \mu \mathrm{g} \mathrm{L}^{-1}(52-93)$ for day $8 ; 72 \mu \mathrm{g} \mathrm{L}^{-1}$ (4487) for day $9 ; 71 \mu \mathrm{g} \mathrm{L}^{-1}$ (42-95) for day 10 and $69 \mu \mathrm{g} \mathrm{L}^{-1}$ (31- 96) for day 11 . The mean survival time $\left(\mathrm{LT}_{50}\right)$ for $17 \mu \mathrm{g} \mathrm{L}^{-1}$ was 18.2 days (15.6-21.3), while that for $50 \mu \mathrm{g} \mathrm{L} \mathrm{L}^{-1}, 12.2$ days (10.7-14.6). Since no significant effects of the intermediate $\mathrm{Cd}$ concentrations were found on mortality and thus, probit lines were non-significant over the experiment, calculations of $\mathrm{LC}_{50}$ and $\mathrm{LT}_{50}$ were not carried out for this metal.

TABLE 1

Friedman ANOVA paired test for effects of $\mathrm{Cd}$ and $\mathrm{Cu}$ concentrations on Capitella sp. Y juvenile mortality $(n=30, d f=1)$

Prueba pareada de ANOVA de Friedman de los efectos de las concentraciones de $\mathrm{Cd}$ y $\mathrm{Cu}$ sobre la mortalidad de juveniles de Capitella sp. $\mathrm{Y}(\mathrm{n}=30, \mathrm{gl}=1)$

\begin{tabular}{|c|c|c|c|c|c|c|c|c|}
\hline \multirow[t]{2}{*}{ Cadmiun } & \multicolumn{2}{|c|}{$60 \mu \mathrm{g} \mathrm{L}^{-1}$} & \multicolumn{2}{|c|}{$160 \mu \mathrm{g} \mathrm{L}^{-1}$} & \multicolumn{2}{|c|}{$240 \mu \mathrm{g} \mathrm{L}^{-1}$} & \multicolumn{2}{|c|}{$340 \mu \mathrm{g} \mathrm{L}^{-1}$} \\
\hline & $\chi^{2}$-value & P-value & $\chi^{2}$-value & P-value & $\chi^{2}$-value & P-value & $\chi^{2}$-value & P-value \\
\hline Control & 7.20 & 0.007 & 0.00 & 1.000 & 3.52 & 0.061 & 22.00 & 0.000 \\
\hline $60 \mu \mathrm{g} \mathrm{L}^{-1}$ & - & - & 8.17 & 0.004 & 19.17 & 0.000 & 3.52 & 0.061 \\
\hline $160 \mu \mathrm{g} \mathrm{L}^{-1}$ & & & - & - & 11.27 & 0.001 & 15.70 & 0.000 \\
\hline $240 \mu \mathrm{g} \mathrm{L}^{-1}$ & & & & & - & - & 18.18 & 0.000 \\
\hline \multirow[t]{2}{*}{ Copper } & \multicolumn{2}{|c|}{$50 \mu \mathrm{g} \mathrm{L}^{-1}$} & \multicolumn{2}{|c|}{$120 \mu \mathrm{g} \mathrm{L}^{-1}$} & \multicolumn{2}{|c|}{$150 \mu \mathrm{g} \mathrm{L}^{-1}$} & & \\
\hline & $\chi^{2}$-value & P-value & $\chi^{2}$-value & P-value & $\chi^{2}$-value & P-value & & \\
\hline Control & 24.00 & 0.000 & 27.00 & 0.000 & 26.00 & 0.000 & & \\
\hline $50 \mu \mathrm{g} \mathrm{L}^{-1}$ & - & - & 14.00 & 0.000 & 13.00 & 0.000 & & \\
\hline $120 \mu \mathrm{g} \mathrm{L}^{-1}$ & & & - & - & 0.33 & 0.564 & & \\
\hline
\end{tabular}


TABLE 2

Mean mortality percentages ( \pm SD) over time of Capitella sp. Y juveniles exposed to Cd $(\mathrm{n}=5$, two replicates $)$

Porcentajes de mortalidad media $( \pm \mathrm{DE})$ de juveniles de Capitella $\mathrm{sp}$. Y expuestos a Cd a través del tiempo $(\mathrm{n}=5$; dos réplicas)

\begin{tabular}{|c|c|c|c|c|c|}
\hline Day & Control & $60 \mu \mathrm{g} \mathrm{L}^{-1}$ & $160 \mu \mathrm{g} \mathrm{L}^{-1}$ & $240 \mu \mathrm{g} \mathrm{L}^{-1}$ & $340 \mu \mathrm{g} \mathrm{L}^{-1}$ \\
\hline 1 & $0.0 \pm 0.0$ & $0.0 \pm 0.0$ & $0.0 \pm 0.0$ & $0.0 \pm 0.0$ & $0.0 \pm 0.0$ \\
\hline 2 & $0.0 \pm 0.0$ & $0.0 \pm 0.0$ & $0.0 \pm 0.0$ & $0.0 \pm 0.0$ & $0.0 \pm 0.0$ \\
\hline 3 & $0.0 \pm 0.0$ & $0.0 \pm 0.0$ & $0.0 \pm 0.0$ & $0.0 \pm 0.0$ & $0.0 \pm 0.0$ \\
\hline 4 & $0.0 \pm 0.0$ & $0.0 \pm 0.0$ & $0.0 \pm 0.0$ & $0.0 \pm 0.0$ & $0.0 \pm 0.0$ \\
\hline 5 & $0.0 \pm 0.0$ & $0.0 \pm 0.0$ & $0.0 \pm 0.0$ & $0.0 \pm 0.0$ & $0.0 \pm 0.0$ \\
\hline 6 & $0.0 \pm 0.0$ & $0.0 \pm 0.0$ & $8.4 \pm 11.8$ & $0.0 \pm 0.0$ & $0.0 \pm 0.0$ \\
\hline 7 & $0.0 \pm 0.0$ & $10.0 \pm 14.1$ & $8.4 \pm 11.8$ & $8.4 \pm 11.8$ & $0.0 \pm 0.0$ \\
\hline 8 & $0.0 \pm 0.0$ & $20.0 \pm 0.0$ & $8.4 \pm 11.8$ & $8.4 \pm 11.8$ & $18.4 \pm 2.3$ \\
\hline 9 & $0.0 \pm 0.0$ & $20.0 \pm 0.0$ & $16.7 \pm 23.5$ & $8.4 \pm 11.8$ & $28.4 \pm 16.5$ \\
\hline 10 & $10.0 \pm 14.1$ & $20.0 \pm 0.0$ & $25.0 \pm 11.7$ & $8.4 \pm 11.8$ & $28.4 \pm 16.5$ \\
\hline 11 & $20.0 \pm 0.0$ & $20.0 \pm 0.0$ & $25.0 \pm 11.7$ & $8.4 \pm 11.8$ & $28.4 \pm 16.5$ \\
\hline 12 & $20.0 \pm 0.0$ & $20.0 \pm 0.0$ & $25.0 \pm 11.7$ & $8.4 \pm 11.8$ & $28.4 \pm 16.5$ \\
\hline 13 & $20.0 \pm 0.0$ & $40.0 \pm 0.0$ & $25.0 \pm 11.7$ & $25.0 \pm 11.7$ & $28.4 \pm 16.5$ \\
\hline 14 & $20.0 \pm 0.0$ & $50.0 \pm 14.1$ & $25.0 \pm 11.7$ & $25.0 \pm 11.7$ & $28.4 \pm 16.5$ \\
\hline 15 & $40.0 \pm 28.3$ & $60.0 \pm 0.0$ & $33.3 \pm 0.0$ & $25.0 \pm 11.7$ & $45.0 \pm 7.1$ \\
\hline 16 & $40.0 \pm 28.3$ & $60.0 \pm 0.0$ & $33.3 \pm 0.0$ & $25.0 \pm 11.7$ & $45.0 \pm 7.1$ \\
\hline 17 & $40.0 \pm 28.3$ & $60.0 \pm 0.0$ & $33.3 \pm 0.0$ & $33.3 \pm 0.0$ & $45.0 \pm 7.1$ \\
\hline 18 & $40.0 \pm 28.3$ & $60.0 \pm 0.0$ & $33.3 \pm 0.0$ & $33.3 \pm 0.0$ & $83.4 \pm 23.5$ \\
\hline 19 & $50.0 \pm 42.4$ & $60.0 \pm 0.0$ & $33.3 \pm 0.0$ & $33.3 \pm 0.0$ & $100.0 \pm 0.0$ \\
\hline 20 & $70.0 \pm 42.4$ & $60.0 \pm 0.0$ & $50.0 \pm 23.6$ & $33.3 \pm 0.0$ & \\
\hline 21 & $70.0 \pm 42.4$ & $60.0 \pm 0.0$ & $50.0 \pm 23.6$ & $33.3 \pm 0.0$ & \\
\hline 22 & $70.0 \pm 42.4$ & $60.0 \pm 0.0$ & $58.4 \pm 11.8$ & $33.3 \pm 0.0$ & \\
\hline 23 & $70.0 \pm 42.4$ & $60.0 \pm 0.0$ & $58.4 \pm 11.8$ & $33.3 \pm 0.0$ & \\
\hline 24 & $70.0 \pm 42.4$ & $70.0 \pm 14.1$ & $58.4 \pm 11.8$ & $41.7 \pm 11.8$ & \\
\hline 25 & $70.0 \pm 42.4$ & $80.0 \pm 28.3$ & $75.0 \pm 11.7$ & $58.4 \pm 11.8$ & \\
\hline 26 & $70.0 \pm 42.4$ & $80.0 \pm 28.3$ & $75.0 \pm 11.7$ & $66.7 \pm 23.5$ & \\
\hline 27 & $80.0 \pm 28.3$ & $90.0 \pm 14.1$ & $75.0 \pm 11.7$ & $75.0 \pm 11.7$ & \\
\hline 28 & $80.0 \pm 28.3$ & $90.0 \pm 14.1$ & $75.0 \pm 11.7$ & $83.3 \pm 0.0$ & \\
\hline 29 & $80.0 \pm 28.3$ & $90.0 \pm 14.1$ & $100.0 \pm 0.0$ & $100.0 \pm 0.0$ & \\
\hline 30 & $100.0 \pm 0.0$ & $100.0 \pm 0.0$ & & & \\
\hline
\end{tabular}


TABLE 3

Mean mortality percentages $( \pm \mathrm{SD})$ over time of Capitella sp. Y juveniles exposed to $\mathrm{Cu}$ $(\mathrm{n}=5$, two replicates $)$

Porcentajes de mortalidad media $( \pm \mathrm{DE})$ de juveniles de Capitella sp. Y expuestos a Cu a través del tiempo $(\mathrm{n}=5$, dos réplicas)

\begin{tabular}{|c|c|c|c|c|}
\hline Day & Control & $50 \mu \mathrm{g} \mathrm{L}^{-1}$ & $120 \mu \mathrm{g} \mathrm{L}^{-1}$ & $150 \mu \mathrm{g} \mathrm{L}^{-1}$ \\
\hline 1 & $0.0 \pm 0.0$ & $0.0 \pm 0.0$ & $0.0 \pm 0.0$ & $0.0 \pm 0.0$ \\
\hline 2 & $0.0 \pm 0.0$ & $0.0 \pm 0.0$ & $0.0 \pm 0.0$ & $0.0 \pm 0.0$ \\
\hline 3 & $0.0 \pm 0.0$ & $0.0 \pm 0.0$ & $30.0 \pm 42.4$ & $0.0 \pm 0.0$ \\
\hline 4 & $0.0 \pm 0.0$ & $0.0 \pm 0.0$ & $40.0 \pm 28.3$ & $35.0 \pm 21.2$ \\
\hline 5 & $0.0 \pm 0.0$ & $0.0 \pm 0.0$ & $90.0 \pm 14.1$ & $100.0 \pm 0.0$ \\
\hline 6 & $0.0 \pm 0.0$ & $10.0 \pm 14.1$ & $100.0 \pm 0.0$ & \\
\hline 7 & $0.0 \pm 0.0$ & $10.0 \pm 14.1$ & & \\
\hline 8 & $0.0 \pm 0.0$ & $20.0 \pm 0.0$ & & \\
\hline 9 & $0.0 \pm 0.0$ & $30.0 \pm 14.1$ & & \\
\hline 10 & $10.0 \pm 14.1$ & $30.0 \pm 14.1$ & & \\
\hline 11 & $20.0 \pm 0.0$ & $40.0 \pm 28.3$ & & \\
\hline 12 & $20.0 \pm 0.0$ & $50.0 \pm 42.4$ & & \\
\hline 13 & $20.0 \pm 0.0$ & $50.0 \pm 42.4$ & & \\
\hline 14 & $20.0 \pm 0.0$ & $50.0 \pm 42.4$ & & \\
\hline 15 & $40.0 \pm 28.3$ & $60.0 \pm 28.3$ & & \\
\hline 16 & $40.0 \pm 28.3$ & $60.0 \pm 28.3$ & & \\
\hline 17 & $40.0 \pm 28.3$ & $100.0 \pm 0.0$ & & \\
\hline 18 & $40.0 \pm 28.3$ & & & \\
\hline 19 & $50.0 \pm 42.4$ & & & \\
\hline 20 & $70.0 \pm 42.4$ & & & \\
\hline 21 & $70.0 \pm 42.4$ & & & \\
\hline 22 & $70.0 \pm 42.4$ & & & \\
\hline 23 & $70.0 \pm 42.4$ & & & \\
\hline 24 & $70.0 \pm 42.4$ & & & \\
\hline 25 & $70.0 \pm 42.4$ & & & \\
\hline 26 & $70.0 \pm 42.4$ & & & \\
\hline 27 & $80.0 \pm 28.3$ & & & \\
\hline 28 & $80.0 \pm 28.3$ & & & \\
\hline 29 & $80.0 \pm 28.3$ & & & \\
\hline 30 & $100.0 \pm 0.0$ & & & \\
\hline
\end{tabular}

The daily observations under the microscope revealed some reduction of the body size and faecal pellets production. These parameters were not quantified, but give us an idea of how metals can affect the exposed specimens. Table 4 contains data concerning the days when these phenomena were observed for the first time in at least one individual.

The production of faecal pellets was observed at the beginning of the experiment since specimens were previously cultured in food-enriched sediment. This condition was maintained over the experiment in the "controls with food". Nevertheless, a reduction of the amount of faecal pellets was observed in the controls and $\mathrm{Cd}$ treatments from day 10. In contrast, this reduction was observed earlier in the $\mathrm{Cu}$ treatments, especially in the highest concentrations (Table 4).

With respect to body size, the "controls with food" experimented a gradual growth over time. In contrast, the loss of body size (length and width) in the controls began from day 14, while for all the Cd treatments, it was observed from the ninth experimental day. Shrinkage was produced earlier in the $\mathrm{Cu}$ treatments that in the $\mathrm{Cd}$ ones. 
The reduction of body size occurred earlier in the highest $\mathrm{Cu}$ concentrations (Table 4).

\section{TABLE 4}

Experimental days from which faecal pellet production and body size reductions of Capitella sp. Y juveniles were observed

Días experimentales a partir de los cuales se observaron disminución en la producción de heces fecales y reducción del tamaño corporal de juveniles de Capitella sp. Y

\begin{tabular}{lcc}
\hline Treatment & $\begin{array}{c}\text { Faecal pellet } \\
\text { reduction }\end{array}$ & $\begin{array}{c}\text { Body size } \\
\text { reduction }\end{array}$ \\
\hline "Controls with food" & No & No \\
Controls & 10 & 14 \\
\hline
\end{tabular}

Cadmium

$60 \mu \mathrm{g} \mathrm{L}-1$

$160 \mu \mathrm{g} \mathrm{L}^{-1}$

$240 \mu \mathrm{g} \mathrm{L}^{-1}$

$340 \mu \mathrm{g} \mathrm{L}-1$

109

10

10

9

$340 \mu \mathrm{g} \mathrm{L}$

10

9

Copper

$50 \mu \mathrm{g} \mathrm{L}{ }^{-1}$

$120 \mu \mathrm{g} \mathrm{L}^{-1}$

$150 \mu \mathrm{g} \mathrm{L}^{-1}$

Daily observations of the specimens under the microscope indicated that all the exposed worms and the controls remained transparent over the experiment. The pinky-reddish appearance of the "controls with food" was observed from days 11-13 (after hatching), which indicated the beginning of haemoglobin production. Continuous tube building was observed in all the controls and exposed juveniles analysed during the experiment.

\section{DISCUSSION}

This study has demonstrated that all the $\mathrm{Cu}$ concentrations tested here and $60 \mu \mathrm{g} \mathrm{\textrm {L } ^ { - 1 }}$ (probably due to the poor physiological condition of some specimens on this treatment) and $340 \mu \mathrm{g} \mathrm{L}^{-1}$ of $\mathrm{Cd}$ produced significant effects on juvenile mortality of Capitella sp. Y. These results as well as the reduction of body size and pellet production observed under the $\mathrm{Cu}$ treatments agree with findings from Reish et al. (1976), Reish (1988) and Reish \& LeMay (1991), who indicated that $\mathrm{Cu}$ and $\mathrm{Hg}$ are the most toxic metals for adults and trochophore larvae of $C$. capitata. Moreover, $50 \mu \mathrm{g} \mathrm{Cu} \mathrm{L} \mathrm{L}^{-1}$ produced suppression of growth rate in the polychaete Ophryotrocha labronica (Brown \& Ahsunallah 1971). In contrast, the effect of $\mathrm{Cd}$ on survival, reproduction, development and life cycles of the polychaetes Ctenodrilus serratus and Ophryotrocha diadema has been demonstrated to be minimal compared to other heavy metals such as $\mathrm{Cu}$ and $\mathrm{Hg}$ (Reish \& Carr 1978). Our results confirm findings by Reish et al. (1976) who showed that $\mathrm{Cd}$ dissolved in water is one of the less harmful heavy metals affecting survivorship in Capitella spp.

Our data were not adequate to obtain a significant fit of the probit lines for $96 \mathrm{~h} \mathrm{LC}_{50}$ due to low mortality. For this reason comparisons of our $\mathrm{LC}_{50}$ and $\mathrm{LT}_{50}$ data for $\mathrm{Cu}$ with previous studies are difficult. The difference in the experimental periods as well as variations in experimental conditions can produce completely different results as shown by Reish et al. (1976) and Reish \& LeMay (1991), whose 96 h LC $_{50}$ results differed during several experiments with the same $C$. capitata population. It was unknown if this difference was due to genetic adaptation or a difference in the experimental protocol. Moreover, Sturmbauer et al. (1999) demonstrated that $\mathrm{LC}_{50}$ values were highly variable among different natural populations of the oligochaete Tubifex tubifex exposed to several $\mathrm{Cd}$ concentrations and concluded that different degrees in resistance could be due, in part, to differences in genotype compositions. Thus, evaluation of responses of different Capitella populations should be interpreted with caution since sensitivity to pollutants varies according to the different sibling species, as has been demonstrated by Méndez (2006) with two Capitella populations exposed to the pesticide teflubenzuron and by Linke-Gamenick et al. (2000a) with three Capitella populations exposed to fluoranthene.

During the experiment, sediment enriched with artificial food was placed in the dishes at the beginning of the experiment and no food was added during the subsequent days to avoid possible changes in the metal concentrations. The scarcity of food was reflected by the reduction of faecal pellets produced by worms and the loss of body size in the controls. It has been demonstrated that Capitella spp. growth 
depends on food availability in the environment (Tenore 1977, Forbes \& Lopez 1990, Tsutsumi et al. 1990).

Juvenile faecal pellet production and body size were strongly reduced in the presence of $\mathrm{Cu}$, while $\mathrm{Cd}$ seems to have minimal effects on feeding and growth of Capitella sp. Y. This fact has been previously demonstrated by Méndez \& Baird (2002) for Capitella sp. I and Capitella sp. B adults. These species did not show significant effects on pellet production and body mass under 60,90 and $140 \mu \mathrm{g} \mathrm{g}^{-1}$ dry weight sediment of Cd. Also Selck et al. (1998) and Selck et al. (1999) demonstrated no significant effects of $50 \mu \mathrm{g} \mathrm{Cd} \mathrm{L^{-1 }}$ on growth rate, egestion rate and worm allometry of Capitella sp. I adults. Considering that Capitella sp. Y juveniles were not fed during the experiment, and that pellet production did not vary according to $\mathrm{Cd}$ concentrations, results obtained here suggest that the scarcity of food had a stronger effect on feeding than that produced by $\mathrm{Cd}$ exposure. On the other hand, worm size varied according to scarcity of food and $\mathrm{Cd}$ concentration, thus a combination of effects on growth is suggested. In contrast, juveniles exposed to $\mathrm{Cu}$ showed an earlier reduction of body size and faecal pellets production compared to the controls, which suggests that this species can be affected by $\mathrm{Cu}$ concentrations as low as $50 \mu \mathrm{g} \mathrm{L}^{-1}$ when food is scarce.

On the other hand, the "controls with food" began to produce haemoglobin from days 11-13 after hatching. The exposed specimens, even the controls, failed to produce haemoglobin during the experiment, which demonstrated that the scarcity of food was responsible rather than metal exposure.

Anguas-Cabrera (2004) demonstrated that lethal concentrations of the organophosphate insecticide methamidophos can inhibit tube building of Capitella sp. Y adults due to its neurotoxic effect. On the contrary, detailed observations during the present experiment indicated that the metals and the scarcity of food in the experimental environment tested here, seem not to produce adverse effects on the tube building activity of Capitella sp. Y juveniles.

This preliminary study indicated that $\mathrm{Cu}$ concentrations ranging from 50 to $150 \mu \mathrm{g} \mathrm{L}^{-1}$ and $340 \mu \mathrm{g} \mathrm{L}^{-1}$ of $\mathrm{Cd}$ can accelerate juvenile mortality of Capitella sp. Y. This fact has important ecological implications since dynamics could be affected in natural populations inhabiting polluted sites. Capitella spp. is an important species-complex in polluted environments because it contributes to the turnover of organic matter and removal of toxic substances from the sediment through its deposit feeding activity. Moreover, $\mathrm{Cd}$ and $\mathrm{Cu}$ accumulated in worm tissues (i.e., Bryan et al. 1980, Eisler 1981) may become more bioavailable for their predators (Ruelas-Inzunza 2001), which could have indirect effects in a community level. Due to the importance of this species-complex and the contemporary metal pollution in the marine environment, further long-term experiments are recommended, especially with $\mathrm{Cu}$, which had a stronger effect on mortality, feeding and growth of the studied population. These studies should consider quantitative data related to feeding and growth in the presence and absence of food, including a higher number of replicates, in order to have a closer approach of the possible injuries produced by this metal on natural populations.

\section{ACKNOWLEDGMENTS}

We want to thank Dilian Anguas, Miguel Betancourt and José Salgado for their help during sampling. Dilian Anguas and Sergio Rendón contributed to maintain the laboratory cultures. We also want to thank Rebeca Garay for her assistance in metal analyses and Neil Duncan for the revision of the final manuscript.

\section{LITERATURE CITED}

ANGUAS-CABRERA DN (2004) Evaluación de la toxicidad del plaguicida organofosforado metamidofos sobre crecimiento y egestión de Capitella sp procedente del estero del Yugo, Mazatlán. Tesis de Maestría, Instituto de Ciencias del Mar y Limnología, Universidad Nacional Autónoma de México, Mazatlán, México. 71 pp.

BROWN B \& M AHSUNALLAH (1971) Effect of heavy metals on mortality and growth. Marine Pollution Bulletin 2: 182-187.

BRYAN GW, WJ LANGSTON \& LG HUMMERSTONE (1980) The use of biological indicators of heavy metal contamination in estuaries with special reference to an assessment of the biological availability of metals in estuarine sediments from south-west Britain. Marine Biological Association of the United Kingdom, Occasional Publication 4: 1-73. 
DUEDALL IW, BH KETCHUM, PK PARK \& R KESTER (1983) Global inputs, characteristics and fates of ocean-dumped industrial and seawage wastes: an overview. In: Duedall IW, BH Ketchum, PK Park \& $\mathrm{R}$ Kester (eds) Wastes in the ocean. Volume 1: industrial and seawage wastes in the ocean: 3-45. John Wiley \& Sons, New York, New York, USA.

CIMM (Centro de Investigación Minera y Metalúrgica) (1996) Evaluación de impacto ambiental en la zona costera de Chañaral: evaluación de impacto ambiental de la depositación de relaves en la zona costera de Chañaral y proposición y evaluación de un plan de descontaminación y medidas de mitigación. Volumen 2. Proyecto P-935112. Centro de Investigación Minera y Metalúrgica, Santiago, Chile. 272 pp.

EISLER R (1981) Trace metal concentrations in marine organisms. Pergamon Press, New York, New York, USA. 685 pp.

FINNEY DJ (1971) Probit analysis. Third edition. Cambridge University Press, Cambridge, United Kingdom. 668 pp.

FORBES TL \& GR LÓPEZ (1990) The effect of food concentration, body size and environmental oxygen tension on the growth of the deposit-feeding polychaete Capitella capitata species 1 . Limnology and Oceanography 35: 1535-1544.

FORBES VE, TL FORBES \& M HOLMER (1996) Inducible metabolism of fluoranthene by the opportunistic polychaete Capitella sp. I. Marine Ecology Progress Series 132: 63-70.

FÖRSTNER U \& GTW WITTMANN (1981) Metal pollution in the aquatic environment. Second revision. Springer-Verlag, Berlin, Germany. $486 \mathrm{pp}$.

GAMENICK I \& O GIERE (1994) Population dynamics and ecophysiology of Capitella capitata from North Sea intertidal flats: evidence for two sibling species. Polychaete Research 16: 44-47.

GAMENICK I, M ABBIATI \& O GIERE (1998a) Field distribution and sulphide tolerance of Capitella capitata (Annelida: Polychaeta) around shallow water hydrothermal vents off Milos (Aegean Sea). A new sibling species? Marine Biology 130: 447-453.

GAMENICK I, B VISMANN, MK GRIESHABER \& O GIERE (1998b) Ecophysiological differentiation of Capitella capitata (Polychaeta). Sibling species from different sulfidric habitats. Marine Ecology Progress Series 175: 155-166.

GRASSLE JF \& JP GRASSLE (1974) Opportunistic life histories and genetic systems in marine polychaetes. Journal of Marine Research 32: 253-284.

GRASSLE JP \& JF GRASSLE (1976) Sibling species in the marine pollution indicator Capitella (Polychaeta). Science 192: 253-284.

LINKE-GAMENICK I, VE FORBES \& N MÉNDEZ (2000a) Effects of chronic fluoranthene exposure on sibling species of Capitella with different development modes. Marine Ecology Progress Series 203: 191-203.

LINKE-GAMENICK I, B VISMANN \& VE FORBES (2000b) Effects of hydrocarbon contamination on survival and metabolism in different sibling species of the Capitella capitata-complex. Marine Ecology Progress Series 194: 169-177.

MÉNDEZ N \& DJ BAIRD (2002) Effects of cadmium on sediment processing in members of the Capitella species-complex. Environmental Pollution 120: 299-305.

MÉNDEZ N, J ROMERO \& J FLOS (1997) Population dynamics and production of the polychaete
Capitella capitata in the littoral zone of Barcelona, Spain. Journal of Experimental Marine Biology and Ecology 218: 263-284.

MÉNDEZ N, I LINKE-GAMENICK \& VE FORBES (2000) Variability in reproductive mode and larval development within the Capitella capitata species complex. Invertebrate Reproduction and Development 38: 131-142.

MÉNDEZ N (2006) Effects of teflubenzuron on sediment processing by members of the Capitella speciescomplex. Environmental Pollution 139: 118-124.

MOODY JR \& RM LINDSTROM (1977) Selection and cleaning of plastic containers for storage of trace element samples. Analytical Chemistry 49: $2264-$ 2267.

NÜRNBERG HW (1977) Potentialities and applications of advanced polarographic and voltammetric methods in environmental research and surveillance of toxic metals. Electrochimica Acta 22: 935- 949.

PEARSON M \& TH PEARSON (1991) Variation in populations of Capitella capitata (Fabricius, 1780) (Polychaeta) from the West coast of Scotland. Ophelia Supplement 5: 363-370.

PEARSON TH \& R ROSENBERG (1978) Macrobenthic succession in relation to organic enrichment and pollution of the marine environment. Oceanography and Marine Biology Annual Review of the United Kingdom 16: 229-311.

REISH DJ (1988) The use of toxicity testing in marine environmental research. In: Soule DF \& GS Kleppel (eds) Marine organisms as indicators: 231-245. Springer-Verlag, New York, New York, USA.

REISH DJ \& RS CARR (1978) The effect of heavy metals on the survival, reproduction, development, and life cycles of two species of polychaetous annelids. Marine Pollution Bulletin 9: 24-27.

REISH DJ \& JA LEMAY (1991) Toxicity and bioconcentration of metals and organic compounds by Polychaeta. Ophelia Supplement 5: 653-660.

REISH DJ, JM MARTIN, FM PILTZ \& JQ WORD (1976) The effect of heavy metals on laboratory populations of two polychaetes with comparisons to the water quality conditions and standards in southern California marine waters. Water Research 10: 299-302.

ROTH I \& H HORNUNG (1977) Heavy metal concentration in water, sediments and fish from Mediterranean coastal areas, Israel. Environmental Science and Technology 11: 265-269.

RUELAS-INZUNZA JR (2001) Concentración y distribución de metales pesados en tejidos de organismos representativos del bajo golfo de California y áreas adyacentes: fauna y flora. Tesis Doctoral, Instituto de Ciencias del Mar y Limnología, Universidad Nacional Autónoma de México, Mazatlán, México. 130 pp.

SELCK H, VE FORBES \& TL FORBES (1998) Toxicity and toxicokinetics of cadmium in Capitella sp. I: relative importance of water and sediment as routes of cadmium uptake. Marine Ecology Progress Series 164: 167-178.

SELCK H, AW DECHO \& VE FORBES (1999) Effects of chronic metal exposure and sediment organic matter on digestive absorption efficiency of cadmium by the deposit-feeding polychaete Capitella species I. Environmental Toxicology and Chemistry 18: 12891297.

STURMBAUER C, BGB OPADIYA, H NIEDERSTÄTTER, A RIEDMANN \& $\mathrm{R}$ DALLINGER (1999) Mitochondrial DNA reveals cryptic oligochaete 
species differing in cadmium resistance. Molecular Biology and Evolution 16: 967-974.

TENORE KR (1977) Growth of Capitella capitata cultured in various levels of detritus from different sources. Limnology and Oceanography 22: 936-941.

TSUTSUMI H, S FUKUNAGA, N FUJITA \& M SUMIDA (1990) Relationships between growth of Capitella sp. and organic enrichment of the sediment. Marine Ecology Progress Series 63: 157-162.

Associate Editor: Matías Medina

Received February 21, 2005; accepted April 29, 2005
WU BL, PY QIAN \& SL ZHANG (1991) Morphology, reproduction, ecology and allozyme electrophoresis of three Capitella sibling species in Qingdao (Polychaeta: Capitellidae). Ophelia Supplement 5: 391-400.

ZAR JH (1996) Biostatistical analysis. Prentice Hall, Englewood Cliffs, New Jersey, USA. 662 pp. + appendixes. 